\title{
Kondisi Kebersihan Lingkungan Berhubungan dengan Risiko Penularan Kasus Leptospirosis di Area Pasar Tradisional
}

\section{Hygene Condition Related to The Transmission Risk of Leptospirosis in Traditional Market Area}

\author{
Dyah Widiastuti*, Dwi Priyanto \\ Balai Penelitian dan Pengembangan Kesehatan Banjarnegara, Badan Litbang Kesehatan, \\ Kementerian Kesehatan RI \\ Jalan Selamanik No 16 A, Banjarnegara, Jawa Tengah, Indonesia \\ *E_mail: umi.azki@gmail.com
}

Received date: 25-06-2020, Revised date: 25-11-2020, Accepted date: 01-12-2020

\begin{abstract}
ABSTRAK
Leptospirosis berkaitan dengan pekerjaan yang berisiko menyebabkan paparan terhadap pekerja ke lingkungan yang terkontaminasi Leptospira patogen. Risiko pajanan leptospirosis di pasar perlu dikaji karena merupakan tempat berkumpul banyak orang sehingga dapat menjadi dasar pengambilan keputusan untuk mengantisipasi terjadinya penularan leptospirosis. Tujuan penelitian ini adalah menentukan hubungan kondisi lingkungan pasar meliputi kebersihan, tingkat kepadatan tikus, dan keberadaan tikus positif leptospira dengan riwayat paparan leptospirosis pada pekerja pasar (pedagang dan petugas kebersihan). Suatu studi cross sectional dilakukan di 35 pasar di Banjarnegara dan 175 pekerja pasar dipilih acak. Sampel darah dianalisis dengan Enzyme Linked Immunosorbent Assay (ELISA) terhadap protein antigen Leptospira patogen (40 Kda). Penangkapan tikus dilakukan di setiap pasar selama dua hari menggunakan 100 perangkap. Tikus yang tertangkap diperiksa dengan Polymerase Chain Reaction (PCR) untuk mendeteksi keberadaan Leptospira dalam ginjalnya. Hasil penelitian menunjukkan bahwa paparan leptospirosis ditemukan pada pedagang dan petugas kebersihan yang tersebar di 17 pasar di Banjarnegara. Hasil pemeriksaan PCR menunjukkan adanya tikus positif terinfeksi Leptospira patogen yang tersebar di empat pasar di Banjarnegara. Uji chi square menunjukkan bahwa kondisi kebersihan di area pasar secara signifikan berpengaruh dengan riwayat pajanan leptospirosis. Pekerja pasar (pedagang dan petugas kebersihan) berisiko terinfeksi leptospirosis, dibuktikan dengan seroprevalensi leptospirosis yang tinggi dalam penelitian ini.
\end{abstract}

Kata kunci: leptospirosis, pasar, kebersihan

\begin{abstract}
Leptospirosis is associated with occupations which exposed workers to contaminated environments. The risk of leptospirosis exposure in the market as a gathering place for many people needs to be assessed, to obtain the basis for decision making to anticipate leptospirosis transmission. This study aimed to determine the relationship between market environmental conditions including market sanitation conditions, the level of rat density and the presence of leptospira-positive rats toward the history of leptospirosis exposure among market workers (traders and janitors). A cross sectional study conducted in 35 markets in Banjarnegara and 175 market workers randomly selected. Blood samples analysed using ELISA against 40 Kda pathogenic Leptospira protein. Rat trapping conducted in each market for two days with 100 traps. The caught mice examined with Polymerase Chain Reaction (PCR) to detect the presence of Leptospira bacteria in their kidneys. Leptospirosis exposure was spread in 17 markets in Banjarnegara. The PCR examination showed that the pathogenic Leptospira infected rats were spread in four markets in Banjarnegara. Chi square test showed that the hygene condition in market area was significantly associated with the leptospirosis exposure. Markets workers (traders and janitors) were at risk for leptospirosis proved by high seroprevalence of leptospirosis in this study.
\end{abstract}

Keywords: leptospirosis, market, hygiene 


\section{PENDAHULUAN}

Leptospirosis adalah penyakit zoonotik yang disebabkan oleh bakteri Leptospira patogen. Penyakit ini setiap tahun dapat menginfeksi paling sedikit 500.000 orang dan menyebabkan kematian sebanyak 60.000 di seluruh dunia. ${ }^{1}$ Kasus leptospirosis masih belum terlaporkan dengan baik karena gejala penyakit ini sulit dibedakan dengan penyakit lain seperti dengue, malaria atau flu. ${ }^{2}$ Kasus leptospirosis di Indonesia pada tahun 2016 berjumlah 833 dengan 62 kematian (CFR 7,44\%), dan pada Tahun 2017 ditemukan 640 kasus dengan 108 kematian (CFR 16,88\%), jumlah kasus meningkat di tahun 2018 menjadi 895 kasus dengan 195 kematian (CFR 16,55\%). ${ }^{3}$ Diantara mamalia, rodent, terutama tikus berperan sebagai reservoir utama leptospirosis. Bakteri ini menetap di tubulus renal inangnya dan diekskresikan ke lingkungan melalui urin. ${ }^{1}$

Leptospirosis diketahui berhubungan erat dengan keberadaan badan air, dimana manusia dapat terinfeksi bila kontak dengan air yang terkontaminasi bakteri Leptospira patogen. Apabila manusia kontak dengan air yang terkontaminasi bakteri Leptospira, bakteri ini akan menembus kulit yang luka atau membran mukosa. ${ }^{1}$

Penularan leptospirosis pada manusia sangat berkaitan dengan faktor pekerjaan. Jenis pekerjaan yang menyebabkan terjadinya kontak antara manusia dengan lingkungan yang terkontaminasi bakteri Leptospira akan memberi risiko yang lebih besar terhadap munculnya kejadian leptospirosis. Jenis pekerjaan yang teridentifikasi memiliki resiko terhadap penularan leptospirosis diantaranya petani, petugas kebersihan, personil militer, dan pekerja di peternakan. ${ }^{4}$ Penelitian yang dilakukan oleh Rahman et al melaporkan tentang seroprevalensi leptospirosis pada populasi pedagang yang menjual daging dan ikan di pasar di Malaysia. ${ }^{4}$ Hasil penelitian tersebut menunjukkan bahwa $33,6 \%$ pekerja pasar di dua pasar induk di Malaysia memiliki riwayat pajanan leptospirosis.
Pasar merupakan tempat transaksi jual beli berbagai komoditas termasuk bahan pangan. Tikus yang hidup di area pasar dapat mengontaminasi bahan-bahan pangan yang disimpan di area pasar, yakni dengan mengonsumsi langsung bahan makanan, merusak bahan makanan, kontaminasi dan menjadi sumber reinfestasi penyakit bagi daerah sekitarnya. ${ }^{5}$ Permasalahan sanitasi di lingkungan pasar tradisional meliputi pembuangan sampah yang tidak tepat, kurangnya suplai air, kurang memadainya fasilitas MCK, dan kontaminasi berbagai agen penular penyakit seperti tikus ataupun lalat. ${ }^{6,7}$ Pasar yang menjadi lokasi penelitian seluruhnya merupakan pasar tradisional. Karakteristik pasar tradisional dijelaskan oleh Rizal, dkk berupa adanya interaksi langsung antara pedagang dan pembeli, bangunan pada pasar tradisional terdiri dari kios-kios atau gerai, los, dan dasaran terbuka yang dibuka penjual maupun suatu pengelola pasar. ${ }^{7}$ Risiko penularan leptospirosis di lingkungan pasar dimungkinkan terjadi karena adanya peluang infestasi hewan reservoir leptospirosis yang cukup besar dan adanya kemungkinan terbentuknya lingkungan yang kondusif untuk pertumbuhan bakeri Leptospira baik berupa genangan air maupun sarana MCK yang tidak terawat. Pada penelitian ini dilakukan survei seroprevalensi riwayat paparan leptospirosis pada populasi pedagang dan petugas kebersihan di pasar di Kabupaten Banjarnegara. Tujuan dari penelitian ini adalah untuk menentukan hubungan kondisi lingkungan pasar di Banjarnegara, meliputi kondisi kebersihan pasar, tingkat kepadatan tikus, dan keberadaan tikus positif Leptospira dengan riwayat paparan leptospirosis di antara para pekerja pasar (pedagang dan petugas kebersihan). Serta mengetahui hubungan pengelolaan pasar dengan kondisi kebersihan pasar dan hubungan kondisi kebersihan lingkungan di pasar dengan keberadaan tikus. 


\section{METODE}

Penelitian ini merupakan studi cross sectional yang dilakukan di 35 pasar di Kabupaten Banjarnegara pada tahun 2019. Total pasar di Banjarnegara ada 67 pasar. Pemilihan sampel pasar pada penelitian ini didasarkan pada wilayah puskesmas. Pasar yang dipilih sebagai sampel adalah pasar yang memiliki jarak terdekat dengan puskesmas di Banjarnegara. Pada setiap pasar diambil 5 orang responden yang mewakili pedagang atau petugas kebersihan pasar. Responden tersebut diambil sampel darah venanya untuk dideteksi riwayat paparan leptospirosis menggunakan ELISA IgG yang spesifik untuk deteksi leptospirosis. Antigen yang digunakan adalah protein bakteri Leptospira interrogans serovar auntumnalis dengan berat molekul $40 \mathrm{Kda}$.

$$
\text { Observasi dilakukan pada saat }
$$

melakukan penangkapan tikus dengan cara pengamatan langsung kondisi pasar. Pasar dikategorikan bersih pada penelitian ini didefinisikan dengan tidak adanya tumpukan sampah di sekitar lapak atau kios yang digunakan untuk berjualan oleh para pedagang dan saluran air yang ada di dalam pasar tidak tersumbat oleh tumpukan sampah. Pasar dikategorikan kotor jika memiliki kondisi lingkungan minimal satu dari tiga kondisi berikut yaitu: lantainya tidak disemen (berupa tanah), terdapat tumpukan sampah, dan saluran air yang di dalam pasar tersumbat oleh tumpukan sampah. Penangkapan tikus dilakukan menggunakan single live trap yang dipasang di kios-kios pasar selama 2 hari.
Dalam perangkap yang dipasang diletakkan umpan berupa mentimun dan ikan asin untuk memikat tikus masuk ke dalam perangkap. Pada masing-masing pasar dipasang perangkap sebanyak 100 buah. Tikus yang tertangkap diambil organ ginjalnya untuk dideteksi keberadaan bakteri Leptospira patogen menggunakan metode Polymerase Chain Reaction (PCR).

Trap sukses dihitung dengan cara menghitung persentase jumlah tikus tertangkap dibagi jumlah perangkap yang digunakan. Kepadatan tikus dikategorikan menjadi 2 yaitu tinggi dan rendah berdasarkan trap sukses dengan nilai cut off point $7 \%{ }^{8}$

Data dianalisis secara bivariat menggunakan uji chi square untuk melihat hubungan antara kondisi kebersihan pasar dan keberadaan tikus yang positif bakteri Leptospira dengan adanya riwayat paparan leptospirosis pada pedagang atau petugas kebersihan di pasar tersebut. Penelitian ini mendapat persetujuan etik dari Komisi Etik Badan Litbang Kesehatan, Kemenkes RI (LB.02.01/2/KE.354/2019, tanggal 5 September 2019).

\section{HASIL}

Hasil deteksi menggunakan ELISA IgG menunjukkan bahwa dari 35 pasar yang diobservasi, $17 \quad(48,6 \%)$ diantaranya ditemukan adanya riwayat paparan leptospirosis pada 31 orang perwakilan pedagang dan petugas kebersihannya (Tabel $1)$. 
Tabel 1. Hasil Deteksi Riwayat Paparan Leptospirosis pada Pedagang dan Petugas Kebersihan Pasar, Kondisi Kebersihan, dan Keberadaan Tikus di Lingkungan Pasar di Kabupaten Banjarnegara

\begin{tabular}{|c|c|c|c|c|c|c|c|}
\hline \multirow[t]{2}{*}{ Kecamatan } & \multirow[t]{2}{*}{ Pasar } & \multicolumn{2}{|c|}{$\begin{array}{l}\text { Responden yang Positif } \\
\text { Ab Leptospirosis }\end{array}$} & \multirow[t]{2}{*}{$\begin{array}{c}\text { Kepadatan } \\
\text { Tikus }\end{array}$} & \multirow{2}{*}{$\begin{array}{c}\text { Deteksi } \\
\text { Leptospira } \\
\text { pada Tikus } \\
\text { Tertangkap }\end{array}$} & \multirow[t]{2}{*}{$\begin{array}{l}\text { Kondisi } \\
\text { Pasar }\end{array}$} & \multirow[t]{2}{*}{ Pengelola } \\
\hline & & Jumlah & Persentase $(\%)$ & & & & \\
\hline \multirow[t]{2}{*}{ Banjarnegara } & Pasar Kota & 1 & 20 & Tinggi & Positif & Kotor & Indagkop \\
\hline & Pasar Salak & 0 & 0 & Tinggi & Negatif & Kotor & Indagkop \\
\hline \multirow[t]{2}{*}{ Madukara } & Madukara & 3 & 60 & Rendah & Negatif & Bersih & Indagkop \\
\hline & Pasar Hewan & 0 & 0 & Tinggi & Negatif & Kotor & Indagkop \\
\hline \multirow[t]{2}{*}{ Rakit } & Rakit & 0 & 0 & Rendah & Negatif & Kotor & Indagkop \\
\hline & Lengkong & 0 & 0 & Tinggi & Negatif & Kotor & Indagkop \\
\hline \multirow[t]{2}{*}{ Punggelan } & Pasar Manis & 1 & 20 & Tinggi & Negatif & Bersih & Indagkop \\
\hline & Danakerta & 0 & 0 & Rendah & Negatif & Bersih & Pemdes \\
\hline \multirow[t]{2}{*}{ Banjarmangu } & Gripit & 0 & 0 & Tinggi & Negatif & Kotor & Pemdes \\
\hline & Beji & 0 & 0 & Tinggi & Negatif & Kotor & Pemdes \\
\hline \multirow[t]{2}{*}{ Sigaluh } & Bandingan & 3 & 60 & Tinggi & Negatif & Bersih & Pemdes \\
\hline & Tunggoro & 5 & 100 & Tinggi & Negatif & Bersih & Indagkop \\
\hline \multirow[t]{2}{*}{ Bawang } & Pucang & 0 & 0 & Rendah & Negatif & Kotor & Pemdes \\
\hline & Wanadri & 3 & 60 & Tinggi & Negatif & Kotor & Indagkop \\
\hline \multirow[t]{2}{*}{ Mandiraja } & Mandiraja & 0 & 0 & Tinggi & Negatif & Kotor & Indagkop \\
\hline & Purwasaba & 0 & 0 & Tinggi & Positif & Kotor & Indagkop \\
\hline \multirow[t]{2}{*}{ Purwonegoro } & Purwonegoro & 0 & 0 & Tinggi & Negatif & Kotor & Indagkop \\
\hline & Merden & 1 & 20 & Tinggi & Negatif & Kotor & Indagkop \\
\hline Purwareja & Klampok & 2 & 40 & Tinggi & Positif & Kotor & Indagkop \\
\hline Klampok & Kecitran & 1 & 20 & Tinggi & Negatif & Kotor & Pemdes \\
\hline \multirow[t]{2}{*}{ Susukan } & Gumelem & 2 & 40 & Tinggi & Negatif & Bersih & Pemdes \\
\hline & Pakikiran & 0 & 0 & Tinggi & Negatif & Kotor & Pemdes \\
\hline Pagedongan & Kebutuh & 1 & 20 & Tinggi & Negatif & Kotor & Pemdes \\
\hline Karang & Karang & 2 & 40 & Rendah & Negatif & Bersih & Indagkop \\
\hline Kobar & Kobar & & & & & & \\
\hline \multirow[t]{2}{*}{ Batur } & Batur & 0 & 0 & Rendah & Negatif & Kotor & Indagkop \\
\hline & Sikidang & 2 & 40 & Tinggi & Positif & Kotor & Indagkop \\
\hline \multirow[t]{2}{*}{ Wanayasa } & Wanayasa & 0 & 0 & Tinggi & Negatif & Bersih & Pemdes \\
\hline & Jatilawang & 1 & 20 & Rendah & Negatif & Kotor & Indagkop \\
\hline Pejawaran & Penusupan & 0 & 0 & Tinggi & Negatif & Kotor & Pemdes \\
\hline \multirow[t]{2}{*}{ Pagentan } & Pagentan & 0 & 0 & Tinggi & Negatif & Bersih & Indagkop \\
\hline & Plunjaran & 0 & 0 & Rendah & Negatif & Kotor & Pemdes \\
\hline Pandanarum & Lawen & 1 & 20 & Tinggi & Negatif & Bersih & Pemdes \\
\hline Kalibening & Kalibening & 1 & 20 & Rendah & Negatif & Bersih & Indagkop \\
\hline \multirow[t]{2}{*}{ Wanadadi } & Wanadadi & 0 & 0 & Tinggi & Negatif & Kotor & Pemdes \\
\hline & Tapen & 1 & 20 & Tinggi & Negatif & Kotor & Pemdes \\
\hline Total & & 31 & 17,7 & & & & \\
\hline \multicolumn{8}{|l|}{ Keterangan : } \\
\hline Indagkop : & $\begin{array}{l}\text { Dinas Perindus } \\
\text { Banjarnegara }\end{array}$ & Per & gan, Kopera & aha Kecil & Menenga & abupaten & \\
\hline Pemdes & Pemerintah De & & & & & & \\
\hline
\end{tabular}

Tabel 1 menunjukkan bahwa $(58,8 \%)$ pasar yang ada riwayat paparan leptospirosis pada perwakilan pedagang dan petugas kebersihannya sebagian besar merupakan pasar yang dikelola oleh pemerintah Kabupaten Banjarnegara dalam hal ini adalah Dinas Perindustrian, Perdagangan, Koperasi dan UKM (10 pasar dari 17 Pasar). Sebagian besar $(37,1 \%)$ pasar yang ada riwayat paparan leptospirosis pada perwakilan pedagang dan petugas kebersihannya memiliki kondisi kebersihan yang kotor.

Penangkapan tikus yang dilakukan di tiap pasar mendapatkan hasil yang bervariasi (trap sukses 2,08-35\%) dengan pengelompokkan dibawah $7 \%$ termasuk kategori kepadatan rendah. Jumlah tikus yang tertangkap dari 35 pasar adalah sebanyak 258 ekor, untuk tikus 
yang tertangkap lebih dari 5 maka pemeriksaan keberadaan bakteri Leptospira menggunakan sistem pengelompokan menjadi 5 pool. Pemeriksaan PCR dari sampel ginjal tikus yang tertangkap menghasilkan data bahwa tikus yang terdeteksi positif Leptospira berasal dari 4 lokasi penangkapan yakni Pasar Kota (18 ekor tertangkap; 1 pool positif), Purwasaba (2 ekor tertangkap; 1 ekor positif), Klampok (18 ekor tertangkap; 1 pool positif) dan Sikidang (13 ekor tertangkap; 1 pool positif).

Tabel 2. Hubungan antara Kondisi Kebersihan, Keberadaan Tikus Positif Leptospira dan Tingkat Kepadatan Tikus dengan Riwayat Paparan Leptospirosis di Lingkungan Pasar di Kabupaten Banjarnegara

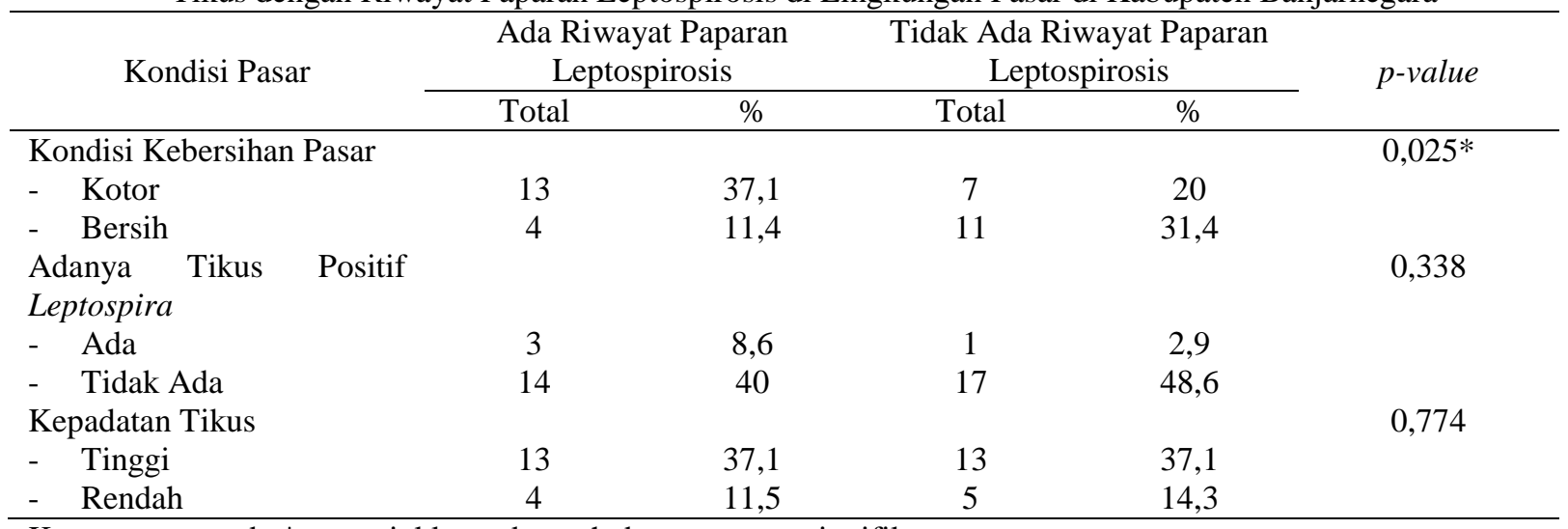

Keterangan: tanda *menunjukkan adanya hubungan yang signifikan

Tabel 2 menunjukkan hasil analisis statistik menggunakan chi square yang menyebutkan bahwa terdapat hubungan signifikan antara kondisi kebersihan pasar dengan adanya riwayat paparan leptospirosis pada perwakilan pedagang dan petugas kebersihan. Tikus berhasil ditangkap dari semua pasar dengan kepadatan yang bervariasi, namun tingkat kepadatan tikus maupun keberadaan tikus yang positif Leptospira dalam pasar tidak berhubungan dengan riwayat paparan leptospirosis. Kondisi kebersihan pasar dipengaruhi oleh kebiasaan pengguna pasar dalam menjaga kebersihan tempat kerjanya. Namun dalam penelitian ini tidak ditemukan adanya hubungan signifikan antara pengelola pasar dengan kondisi kebersihan pasar (Tabel 3).

Tabel 3. Hubungan Pihak Pengelola Pasar dengan Kondisi Kebersihan Pasar

\begin{tabular}{lcccccc} 
& Jumlah & \multicolumn{2}{c}{ Kotor } & \multicolumn{2}{c}{ Bersih } & T-value \\
\cline { 5 - 7 } & Pasar & Total & $\%$ & Total & $\%$ & 0,767 \\
\hline $\begin{array}{l}\text { Pihak Pengelola Pasar } \\
\text { Pemerintah }\end{array}$ & 35 & 11 & 37,1 & 9 & 20 & \\
$\quad \begin{array}{l}\text { Kabupaten } \\
\text { Pemerintah Desa }\end{array}$ & & 9 & 11,4 & 6 & 31,4 \\
\hline
\end{tabular}

Tabel 4. Hubungan Kondisi Kebersihan Pasar dengan Kepadatan Tikus

\begin{tabular}{|c|c|c|c|c|c|c|c|}
\hline & & \multirow{3}{*}{$\begin{array}{c}\text { Jumlah } \\
\text { Pasar }\end{array}$} & \multicolumn{4}{|c|}{ Kepadatan Tikus } & \multirow{3}{*}{$p$-value } \\
\hline & & & \multicolumn{2}{|c|}{ Tinggi } & \multicolumn{2}{|c|}{ Rendah } & \\
\hline & & & Total & $\%$ & Total & $\%$ & \\
\hline $\begin{array}{l}\text { Kondisi } \\
\text { Pasar }\end{array}$ & Lingkungan & 35 & & & & & 0,589 \\
\hline - $\quad$ Kotor & & & 15 & 42,8 & 5 & 14,3 & \\
\hline - $\quad$ Bersih & & & 10 & 28,6 & 5 & 14,3 & \\
\hline
\end{tabular}




\section{PEMBAHASAN}

Leptospirosis merupakan salah satu penyakit infeksi yang berhubungan dengan pekerjaan dan aktivitas yang meningkatkan interaksi antara manusia, hewan penular, dan lingkungan yang terkontaminasi. Baik hewan domestik maupun liar dapat menyebarkan bakteri Leptospira melalui urinnya. Namun demikian, sebagian besar infeksi pada manusia dikaitkan dengan keberadaan tikus. ${ }^{4}$

Dalam penelitian ini, persentase responden yang mempunyai riwayat terpapar leptospirosis cukup tinggi $(17,7 \%)$, namun tidak diketahui waktu dan tempat mereka terpapar penyakit karena keterbatasan penelitian untuk melacak hal tersebut. Sebanyak 48,6\% pasar di Kabupaten Banjarnegara memiliki pekerja pasar dengan riwayat pajanan leptospirosis. Angka seroprevalensi leptospirosis pada pekerja pasar yang ditemukan dalam penelitian ini lebih rendah jika dibandingkan dengan penelitian Rahman et al di Malaysia yang melaporkan bahwa seroprevalensi leptospirosis pada pekerja pasar di dua pasar induk di Malaysia sebesar $33,6 \%$.

Penelitian hanya menggambarkan bahwa responden yang positif pernah terpapar leptospirosis mendapatkan sumber paparan yang berasal dari pasar tempat mereka bekerja, mengingat responden yang berpartisipasi dalam penelitian ini adalah pedagang dan petugas kebersihan yang sebagian besar waktunya berada di lingkungan pasar. Kelemahan lain dalam penelitian ini adalah jumlah responden yang cukup terbatas, yaitu sebanyak lima orang di setiap pasar. Meskipun unit analisis dalam penelitian ini adalah pasar, namun jumlah responden yang mewakili masing-masing pasar akan berpengaruh terhadap tinggi rendahnya nilai seroprevalensi yang diperoleh. Jumlah responden ini tentunya kurang bisa mewakili populasi pedagang dan petugas kebersihan di pasar.

Lingkungan di sekitar pasar memiliki kondisi yang mendukung untuk infestasi tikus karena tersedianya sumber pakan dan tempat untuk membuat sarang. ${ }^{6}$ Penelitian ini menunjukkan kondisi kebersihan pasar berhubungan dengan riwayat paparan leptospirosis. Kondisi yang tidak higienis dan tumpukan sampah menjadi faktor yang dapat menarik tikus untuk membuat sarang di lingkungan pasar. Kelembaban di lingkungan pasar cenderung tinggi sehingga memungkinkan bagi bakteri Leptospira bertahan hidup di lingkungan tersebut. ${ }^{1}$

Kondisi pasar dengan banyak tumpukan sampah menyebabkan tersumbatnya saluran air yang telah disediakan di antara kios-kios pedagang. Hal ini akan berpotensi menimbulkan genangan air khususnya pada musim penghujan. Drainase yang tidak baik dapat menyebabkan munculnya genangan air yang menjadi media penularan leptospirosis ke manusia. ${ }^{9,10}$ Salah satu moda trasmisi Leptospira masuk ke tubuh manusia adalah melalui luka terbuka yang terpapar dengan air yang terkontaminasi bakteri Leptospira. ${ }^{11}$

Penangkapan tikus yang dilakukan menunjukkan bahwa tikus terdapat di semua pasar yang disurvei sehingga sangat memungkinkan adanya potensi penularan leptospirosis di lokasi penelitian, mengingat tikus adalah reservoir utama bakteri Leptospira. ${ }^{12}$ Hasil uji menunjukkan bahwa kepadatan tikus tidak berhubungan dengan riwayat paparan leptospirosis. Hal ini dapat dipengaruhi karena terbatasnya jumlah responden yang diambil untuk diperiksa riwayat pajanan leptospirosis. Demikian juga kondisi kebersihan pasar tidak berhubungan dengan tingkat kepadatan tikus. Penangkapan tikus dalam penelitian ini dilakukan selama satu malam pada tiap pasar. Hasil penangkapan sangat bervariasi yang menunjukkan kepadatan tikus pada tiap pasar yang disurvei. Namun kepadatan ini sangat relatif karena hanya berdasarkan angka trap success. ${ }^{13}$ Penelitian lain menyebutkan bahwa keberadaan tikus sangat erat hubungannya dengan kondisi sanitasi, yang pada gilirannya juga meningkatkan potensi zoonosis bersumber tikus. ${ }^{12,14}$

Keberhasilan penangkapan tikus bergantung pada beberapa faktor. Tikus 
diketahui mempunyai sifat neofobia, mereka cenderung berhati-hati terhadap benda yang dianggap baru. ${ }^{15}$ Durasi penangkapan yang hanya satu malam tidak memberikan kesempatan tikus untuk beradaptasi dengan perangkap yang digunakan sehingga hal ini tentu berpengaruh terhadap tikus yang berhasil ditangkap. Faktor lain adalah umpan yang digunakan. Preferensi tikus terhadap umpan juga berbeda-beda, mereka cenderung lebih familiar dengan makanan yang biasa didapatkan di sekitar tempat hidupnya yang terbukti "aman". ${ }^{15,16}$ Karakteristik pasar yang terdapat berbagai jenis makanan yang bisa diperoleh tikus menyulitkan pemilihan jenis umpan.

Sebagian besar pasar yang ada riwayat paparan leptospirosis pada perwakilan pedagang dan petugas kebersihannya merupakan pasar yang dikelola oleh Dinas Indakop (Dinas Perindustrian, Perdagangan, Koperasi, Usaha Kecil dan Menengah Kabupaten Banjarnegara). Pada umumnya, pasar yang dikelola oleh Dinas Indakop berukuran lebih besar dibanding pasar yang dikelola pemerintah desa. Selain itu, pasar yang dikelola Dinas Indakop aktif setiap hari, sedangkan pasar yang dikelola desa hanya aktif pada hari-hari tertentu. Namun hasil analisis menunjukkan bahwa tidak ada hubungan antara pengelola pasar dengan tingkat kebersihan. Kondisi kebersihan pasar dalam penelitian ini mungkin lebih dipengaruhi oleh perilaku pedagang ataupun kinerja petugas kebersihan yang berbeda pada masing-masing pasar, bukan dari sistem manajemen pengelolaan pasar. Penelitian yang dilakukan oleh Pratiwi dan Kartika menunjukkan bahwa setelah dilakukan revitalisasi di Pasar Pohgading menjadi pasar berstandar SNI, kebersihan di pasar tersebut menjadi meningkat. Penelitian ini menunjukkan bahwa adanya perubahan sistem, meskipun dengan SDM yang sama akan menghasilkan output yang berbeda. ${ }^{17}$

Adanya riwayat paparan leptospirosis pada perwakilan pedagang dan petugas kebersihan di lingkungan pasar di Kabupaten
Banjarnegara didukung dengan ditemukannya tikus positif Leptospira di lingkungan tersebut. Namun demikian, hasil analisis statistik menunjukkan tidak adanya hubungan antara keberadaan tikus positif Leptospira dengan adanya riwayat paparan leptospirosis pada perwakilan pedagang dan petugas kebersihan di pasar. Variabel yang memiliki hubungan dengan adanya riwayat paparan leptospirosis pada perwakilan pedagang dan petugas kebersihan di lingkungan pasar adalah kondisi kebersihan pasar.

Pasar tradisional masih merupakan tempat yang sangat banyak diakses oleh masyarakat Indonesia, meskipun banyak pasar modern yang terdapat di daerah perkotaan. Peran vital dalam bidang ekonomi ini menimbulkan efek lain dalam bidang kesehatan khususnya terkait dengan penularan penyakit. Kondisi pasar tradisional yang kurang bersih akan meningkatkan risiko terjadinya penularan penyakit. ${ }^{3,18}$

Rejeki menjelaskan bahwa salah satu faktor yang berpengaruh terhadap kejadian leptospirosis berat adalah adanya sampah di dalam rumah $(\mathrm{OR}=4,1) \cdot{ }^{19}$ Sampah yang berupa sisa bahan makanan dapat dimanfaatkan oleh tikus. Keberadaan sampah di suatu lingkungan merupakan indikator sanitasi yang buruk dan menyebabkan adanya infestasi tikus di lingkungan tersebut. ${ }^{9} \mathrm{Hal}$ ini dikarenakan tikus senang berkeliaran di tempat sampah untuk mencari makanan. Jika di sekitar lapak penjual banyak ditemukan sampah, maka tikus akan banyak beraktivitas di sekitar lapak tersebut. Adanya tikus yang sering beraktivitas di suatu lingkungan akan memperbesar resiko terjadinya penularan leptospirosis. ${ }^{20}$ Oleh karena itu, upaya yang sangat penting untuk dilakukan dalam mencegah terjadinya penularan penyakit leptospirosis adalah dengan meningkatkan kebersihan di lingkungan pasar. Diharapkan dengan kondisi pasar yang bersih akan meminimalisir tikus yang beraktivitas di sekitar lapak penjual, sehingga kontaminasi bakteri Leptospira patogen dapat dikurangi semaksimal mungkin. 


\section{KESIMPULAN}

Adanya riwayat paparan leptospirosis pada $17,7 \%$ perwakilan pedagang dan petugas kebersihan di lingkungan pasar menunjukkan adanya potensi penularan leptospirosis di area tersebut. Faktor yang secara signifikan berhubungan dengan riwayat paparan leptospirosis di lingkungan pasar adalah kondisi kebersihan lingkungan.

\section{SARAN}

Dalam rangka meningkatkan kesadaran masyarakat pasar terhadap pentingnya menjaga kebersihan lingkungan, diperlukan adanya gerakan membersihkan lingkungan yang dilakukan secara serentak dan berkala.

\section{KONTRIBUSI PENULIS}

Penulis dalam artikel ini adalah DW, sebagai kontributor utama yang bertanggung jawab dalam konsep penulisan artikel secara menyeluruh, dan DP sebagai kontributor anggota yang bertanggung jawab dalam metodologi dan analisis data.

\section{UCAPAN TERIMA KASIH}

Penulis mengucapkan terima kasih kepada Kepala Balai Litbangkes Banjarnegara atas bimbingannya selama pelaksanaan penelitian.

\section{DAFTAR PUSTAKA}

1. Haake DA, Levett PN. Leptospirosis in human. In: Adlers B, ed. Leptospira and Leptospirosis. Springer; 2015. p.65-97. doi:10.1007/978-3662-45059-8_5.

2. Garba B, Bahaman AR, Bejo SK, Zakaria Z, Rahim A, Bande F. Major epidemiological factors associated with leptospirosis in Malaysia. Acta Trop. 2018;178:242-7. doi:10.1016/j.actatropica.2017.12.010.

3. Kementerian Kesehatan RI. Profil kesehatan Indonesia tahun 2019. Jakarta: Kementerian Kesehatan RI; 2020.

4. Rahman MHAA, Hairon SM, Hamat RA, Jamaludin TZMT, Shafei MN, Idris N, et al. Seroprevalence and distribution of leptospirosis serovars among wet market workers in northeastern, Malaysia: a cross sectional study. BMC Infect Dis. 2018;18(569):1-5. doi:10.1186/s12879-018$3470-5$.

5. Widiastuti D, Pramestuti N, Setiyani E, Rahayu HF. Mikroorganisme patogen pada feses tikus. J Kesehat Masy Nas. 2013;8(4):174-78.

doi:10.21109/kesmas.v0i0.396.

6. Manaf FA, Achmadi UF. Studi eksploratif faktor risiko pasar tradisional Tahun 2018 (studi di Pasar Bantar Gebang, Kota Bekasi). J Nas Kesehat Lingkung Glob. 2020;1(2):75-84.

7. Rizal RM, Alhamidi NR, Hermawan F, Ismiyati. Karakteristik lokasi pasar tradisional dan dampak operasionalnya: studi kasus Kota Semarang. J Riptek. 2017;2(2):71-82.

8. Dewi WM, Partaya, Susanti R. Prevalensi ektoparasit pada tikus sebagai upaya pemetaan risiko zoonosis di kawasan rob Kota Semarang. J Ekol Kesehat. 2019;18(3):171-82. doi:10.22435/jek.v3i18.2133.

9. Soo ZMP, Khan NA, Siddiqui R. Leptospirosis: increasing importance in developing countries. Acta Trop. 2020;201. doi:10.1016/j.actatropica.2019.105183.

10. Daud A, Fuzi NMHM, Mohammad WMZW, Amran F, Ismail N, Arshad MM, et al. Leptospirosis and workplace environmental risk factors among cattle farmers in Northeastern Malaysia. Int J Occup Environ Med. 2018;9(2):88-96. doi:10.15171/ijoem.2018.1164.

11. Allan KJ, Biggs HM, Halliday JEB, Kazwala RR, Maro VP, Cleaveland S, et al. Epidemiology of leptospirosis in Africa: a systematic review of a neglected zoonosis and a paradigm for 'one health' in Africa. PLoS Negl Trop Dis. 2015;9(9):1-25. doi:10.1371/journal.pntd.0003899.

12. Santos N de J, Sousa E, Reis MG, Ko AI, Costa F. Rat infestation associated with environmental deficiencies in an urban slum community with high risk of leptospirosis transmission. Cad Saude Publica. 2017;33(2):1-13. doi:10.1590/0102$311 \mathrm{X} 00132115$.

13. Ikawati B, Nurjazuli. Analisis karakteristik lingkungan pada kejadian leptospirosis di Kabupaten Demak Jawa Tengah tahun 2009. Media Kesehat Masy. 2010;9(1):33-40. 
doi:10.14710/mkmi.9.1.33-40.

14. Dobigny G, Garba M, Tatard C, Loiseau A, Galan M, Kadaoure, et al. Urban market gardening and rodent-borne pathogenic Leptospira in arid zones: a case study in Niamey, Niger. PLOS Neglected Trop Dis. 2015;9(10):1-15.

doi:10.1371/journal.pntd.0004097.

15. Saragih RKP, Martini, Tarwatjo U. Jenis dan kepadatan tikus di panti asuhan " $\mathrm{X}$ " Kota Semarang. J Kesehat Masy. 2019;7(1):260-70.

16. Takács S, Musso AE, Gries R, Rozenberg E, Borden JH, Brodie B, et al. New food baits for trapping house mice, black rats and brown rats. Appl Anim Behav Sci. Published online 2017. doi:10.1016/j.applanim.2017.11.011.

17. Pratiwi KC, Kartika IN. Analisis efektivitas program revitalisasi pasar tradisional dan dampaknya terhadap pendapatan pedagang dan pengelolaan Pasar Pohgading. E-Jurnal
Ekonomi dan Bisnis Universitas Udayana. 2019;8(7):805-34 .

doi:10.24843/EEB.2019.v08.i07.p06.

18. Tsinda A, Abbott P, Chenoweth J. Sanitation markets in urban informal settlements of East Africa. Habitat Int. 2015;49:21-9. doi:10.1016/j.habitatint.2015.05.005.

19. Rejeki DSS. Faktor risiko lingkungan yang berpengaruh terhadap leptospirosis berat (studi kasus di Rumah Sakit Dr. Kariadi Semarang). (Tesis). Prodi Epidemiologi Program Pascasarjana: Universitas Diponegoro Semarang. Published online 2005.

20. Jittimanee J, Wongbutdee J. Prevention and control of leptospirosis in people and surveillance of the pathogenic Leptospira in rats and in surface water found at villages. $\mathbf{J}$ Infect Public Health. 2019;12(5):705-11. doi:10.1016/j.jiph.2019.03.019. 
BALABA Vol. 16 No. 2, Desember 2020: 199-208 